\title{
Influence of time and storage temperature on raw milk deteriorating microbiota
}

\author{
Influência do tempo e temperatura de estocagem sobre a microbiota \\ deteriorante do leite cru
}

\author{
Jhennifer Arruda Schmiedt ${ }^{1}$ (D); Leonardo Ereno Tadielo ${ }^{1}$ (D); Thiago Henrique Bellé ${ }^{1}$ (1); \\ Carolina Dias Rodrigues $^{1}$ (D); Maike Tais Maziero Montanhini ${ }^{1}$ (D); Vinicius Cunha Barcellos ${ }^{1}$ (D); \\ Luciano dos Santos Bersot ${ }^{1}$
}

${ }^{1}$ Universidade Federal do Paraná, Laboratório de Inspeção e Controle de Qualidade de Alimentos e Água, Palotina - PR, Brazil

\begin{abstract}
The quality of raw milk depends on initial microbial contamination and conditions of storage until industry processing. Considering the influence of time and storage temperature on raw milk microbiota, the objective of this work was to quantify and monitor the multiplication of these groups under different conditions. For this purpose, 41 samples of raw milk were collected immediately after milking, stored in the following storage conditions: $25^{\circ} \mathrm{C} / 2 \mathrm{~h} ; 35^{\circ} \mathrm{C} / 2 \mathrm{~h} ; 7^{\circ} \mathrm{C} / 24 \mathrm{~h}$; $7^{\circ} \mathrm{C} / 48 \mathrm{~h}$ and $7^{\circ} \mathrm{C} / 60 \mathrm{~h}$ and analyses of aerobic mesophilic, psychrotrophic and proteolytic psychrotrophic microorganisms. The milk samples analyzed in the study had an initial mean count of mesophilic aerobes of $5.38 \mathrm{Log} \mathrm{CFU} / \mathrm{mL}$ at Time Zero. The milk stored at $25^{\circ} \mathrm{C} / 2 \mathrm{~h}$ and $35^{\circ} \mathrm{C} / 2 \mathrm{~h}$ kept the mesophilic aerobic counts within the limits established by the legislation (5.48 Log CFU/mL), with an increase in counts of psychrotrophic and proteolytic microorganisms. When stored at $7{ }^{\circ} \mathrm{C} / 24 \mathrm{~h}$ and $7{ }^{\circ} \mathrm{C} / 48 \mathrm{~h}$, the count of mesophiles exceeded the established parameters. A significant increase in the count of proteolytic psychrotrophs and psychrotrophs was also observed during storage at $7^{\circ} \mathrm{C}$ from $24 \mathrm{~h}$. The results of this study indicate that the temperature of $7{ }^{\circ} \mathrm{C}$ is not suitable for the milk conservation, since it was not able to control the microbial multiplication. Thus, the results contribute to the change in milk storage temperature proposed by the new Brazilian legislation.
\end{abstract}

Keywords: Legislation. Mesophiles. Proteolytic. Psychrotrophic.

\section{RESUMO}

A qualidade do leite cru depende da contaminação microbiana inicial e das condições de armazenamento até o processamento na indústria. Considerando a influência do tempo e da temperatura de armazenamento na microbiota do leite cru, o objetivo deste trabalho foi quantificar e monitorar a multiplicação desses grupos de microrganismos sob diferentes condições. Para tanto, foram coletadas 41 amostras de leite cru imediatamente após a ordenha, armazenadas nas seguintes condições de armazenamento: $25^{\circ} \mathrm{C} / 2 \mathrm{~h} ; 35^{\circ} \mathrm{C} / 2 \mathrm{~h} ; 7^{\circ} \mathrm{C} / 24 \mathrm{~h} ; 7^{\circ} \mathrm{C} / 48 \mathrm{~h}$ e $7{ }^{\circ} \mathrm{C} / 60 \mathrm{~h}$ para análise de microrganismos psicrotróficos, aeróbios mesófilos, psicrotróficos e proteolíticos. As amostras de leite analisadas no estudo apresentaram uma contagem média inicial de aeróbios mesófilos de $5.38 \mathrm{Log}$ UFC/mL no Tempo Zero. O leite armazenado a $25^{\circ} \mathrm{C} / 2 \mathrm{~h} \mathrm{e} 35^{\circ} \mathrm{C} / 2 \mathrm{~h}$ manteve as contagens aeróbias mesófilas dentro dos limites estabelecidos pela legislação (5,48 Log UFC/mL), com aumento nas contagens de microrganismos psicrotróficos e proteolíticos. Quando armazenado a $7^{\circ} \mathrm{C} / 24$ h e $7^{\circ} \mathrm{C} / 48 \mathrm{~h}$ a contagem de mesófilos excedeu os parâmetros estabelecidos. Um aumento significativo na contagem de psicrotróficos e psicrotróficos proteolíticos também foi observado durante o armazenamento a $7^{\circ} \mathrm{Ca}$ partir das $24 \mathrm{~h}$. Os resultados deste estudo indicam que a temperatura de $7^{\circ} \mathrm{C}$ não é adequada para a conservação do leite, uma vez que não foi capaz de controlar a multiplicação microbiana. Assim, os resultados contribuem para a mudança na temperatura de armazenamento de leite proposta pela nova legislação brasileira.

Palavras-chave: Legislação. Mesófilos. Proteolíticos. Psicrotróficos. 


\section{Correspondence to:}

Luciano dos Santos Bersot

Universidade Federal do Paraná, Laboratório de Inspeção e

Controle de Qualidade de Alimentos e Água

Endereço: Rua Pioneiro, 2153, Jardim Dallas

CEP: 85950-000, Palotina - PR, Brazil

e-mail: lucianobersot@ufpr.br

Received: April 15, 2019

Approved: September 23, 2019

How to cite: Schmiedt JA, Tadielo LE, Bellé TH, Rodrigues CD, Montanhini MTM, Barcellos VC, Bersot LS. Influence of time and storage temperature on raw milk deteriorating microbiota. Braz J Vet Res Anim Sci. 2020;57(1):e156883. https://doi.org/10.11606/issn.1678-4456.bjvras.2020.156883

\section{Introduction}

The microbiological quality of raw milk is closely related to two aspects: microbial contamination and multiplication rate of microorganisms. In this sense, with regard to the first aspect, the health of the mammary gland, microbiota from the outside of the udder, contamination of the equipment and microbiological quality of the water are considered; with respect to the second, the binomial time/temperature in which the milk remains from milking to processing is considered (Nada et al., 2012).

Rapid reduction in milk temperature after milking is one of the most effective strategies to ensure good microbiological quality of the product. However, cooling the milk alone is not a guarantee of quality. Prolonged or marginal temperature refrigeration selects the psychrotrophic bacteria, deteriorating microorganisms that have a multiplication capacity of $7{ }^{\circ} \mathrm{C}$ or less, regardless of the optimal multiplication temperature (McPhee \& Griffiths, 2011). Although these microorganisms are destroyed by pasteurization, they produce thermoresistant extracellular enzymes during their multiplication, mainly lipases and proteases, which act on milk components even after their thermal treatment (Murphy et al., 2016).

The Normative Instruction 62 (IN62) (Ministério da Agricultura, Pecuária e Abastecimento, 2011), amended by Normative Instruction 31 (IN31) (Ministério da Agricultura, Pecuária e Abastecimento, 2018a), which provided for the microbiological standards for refrigerated raw milk, pasteurized milk and type A milk, were repealed by Normative Instruction 76 (IN76) (Ministério da Agricultura, Pecuária e Abastecimento, 2018b), which determines that raw milk must be kept refrigerated at a maximum of $7{ }^{\circ} \mathrm{C}$ in rural properties and also establishes new parameters on total bacterial count. The permanence of milk in the properties can be of maximum $48 \mathrm{~h}$, with a recommended ideal time period not exceeding $24 \mathrm{~h}$. Milk must be collected in trucks equipped with isothermal tanks and sent to the industrial facilities for processing. Therefore, refrigerated raw milk is allowed to oscillate up to $2^{\circ} \mathrm{C}$ from the original temperature, and it is not allowed to exceed $9{ }^{\circ} \mathrm{C}$ in the industry receiving platform (Ministério da Agricultura, Pecuária e Abastecimento, 2018b).

According to the aforementioned information, the objectives of the present study were to quantify the main microbial groups in raw milk obtained immediately after milking and to follow the multiplication of these groups submitted to different conditions of storage time and temperature.

\section{Materials and Methods}

This study was carried out between April 2016 and September 2017 in dairy farms in the western region of Paraná. The properties were selected with the support of the cooperative which provides the technical assistance according to the following characteristics: own mechanized milking system and storage in tanks of direct expansion. In each property, a sample was collected directly from the expansion tank, immediately after the first milking of the day, without accumulations of previous milking, totaling 41 samples. Each sample was composed of an approximate volume of $300 \mathrm{~mL}$, collected aseptically in sterile flasks, packaged in isothermal boxes and taken to the Laboratory of Inspection and Quality Control of Food and Water (LACOMA), Department of Veterinary Sciences (DCV) of the Federal University of Paraná (UFPR), Sector Palotina, and the analyses began within $2 \mathrm{~h}$ after the gathering, called "Zero Time". The remaining samples were fractionated in 5 flasks, which were submitted to simulations of the following time/storage temperature binomials: $25^{\circ} \mathrm{C} / 2 \mathrm{~h} ; 35^{\circ} \mathrm{C} / 2 \mathrm{~h}$; $7^{\circ} \mathrm{C} / 24 \mathrm{~h} ; 7^{\circ} \mathrm{C} / 48 \mathrm{~h}$ and $7^{\circ} \mathrm{C} / 60 \mathrm{~h}$. The simulations of $25^{\circ} \mathrm{C} / 2 \mathrm{~h}$ and $35^{\circ} \mathrm{C} / 2 \mathrm{~h}$ were adopted in order to reproduce situations of transfer to the industrial establishment at room temperature. The simulations $7^{\circ} \mathrm{C} / 24 \mathrm{~h}$ and $7^{\circ} \mathrm{C} / 48 \mathrm{~h}$ were determined mimicking situations which are acceptable by the legislation for receiving milk in the facility, while the $7^{\circ} \mathrm{C} / 60 \mathrm{~h}$ condition represents the time extrapolation that is allowed.

After each storage condition, the samples were submitted to analysis of the following microbial groups:

- Mesophiles: pour plate method in plate count agar (PCA) and incubation at $36{ }^{\circ} \mathrm{C}$ for $48 \mathrm{~h}$ (Laird et al., 2004); 
- Psychrotrophic: spread plate method in plate count agar (PCA) and incubation at $7{ }^{\circ} \mathrm{C}$ for 10 days (Downes \& Ito, 2001);

- Proteolytic Psychrotrophic: imprint transfer of plate with psychrotrophic counts between 20-200 colonies on a $10 \%$ milk agar plate followed by incubation at $7{ }^{\circ} \mathrm{C}$ for 10 days (Frank et al., 2004).

For the statistical analysis, the SPSS Program version 19 was used, through descriptive statistics. The averages were compared one by one by the $t$-test for paired samples, with significance level $\mathrm{p}<0.05$.

\section{Results and Discussion}

The milk samples analyzed in the study had an initial mean count of mesophilic aerobes of $5.38 \mathrm{Log} \mathrm{CFU} / \mathrm{mL}$ at Time Zero (Table 1). The milk stored for $2 \mathrm{~h}$ at $25^{\circ} \mathrm{C}$ and $35^{\circ} \mathrm{C}$ kept the mesophilic aerobic counts within the limits established by current legislation (5.48 Log CFU/mL) and did not present a significant difference with Time Zero (Ministério da Agricultura, Pecuária e Abastecimento, 2018b). The IN31 allowed the milk to be kept at room temperature for delivery to the dairy in up to $2 \mathrm{~h}$, provided that the microbiological parameters of the refrigerated milk were respected. Therefore, the study showed that the conditions of $25^{\circ} \mathrm{C} / 2 \mathrm{~h}$ and $35^{\circ} \mathrm{C} / 2 \mathrm{~h}$ did not alter the microbiological quality of the milk for this microbial group, which was not observed on the counts of psychrotrophic and proteolytic microorganisms $(\mathrm{p}<0.05)$.

When stored at $7{ }^{\circ} \mathrm{C} / 24 \mathrm{~h}$, the mesophile count did not differ statistically compared to Time Zero ( $\mathrm{p}>0.05)$. However, this condition allowed a numerical increase of the bacterial count that exceeded the acceptable limit, possibly by the increase of psychrotrophic and proteolytic microorganisms (Figure 1). An increase in counts of mesophilic microorganisms was observed in the milk stored at $7{ }^{\circ} \mathrm{C}$ after $48 \mathrm{~h}$ and $60 \mathrm{~h}(\mathrm{p}<0.05)$, showing that these combinations were not adequate for the milk conservation, since they did not maintain the microbial contamination within the expected limits by IN31.

The initial contamination, along with storage conditions (time/temperature), exerted a strong impact on bacterial count, as well as on the profile of the microorganisms found in milk (Paludetti et al., 2018), which was also observed in the present study (Figure 1). The storage at $7{ }^{\circ} \mathrm{C}$ has been

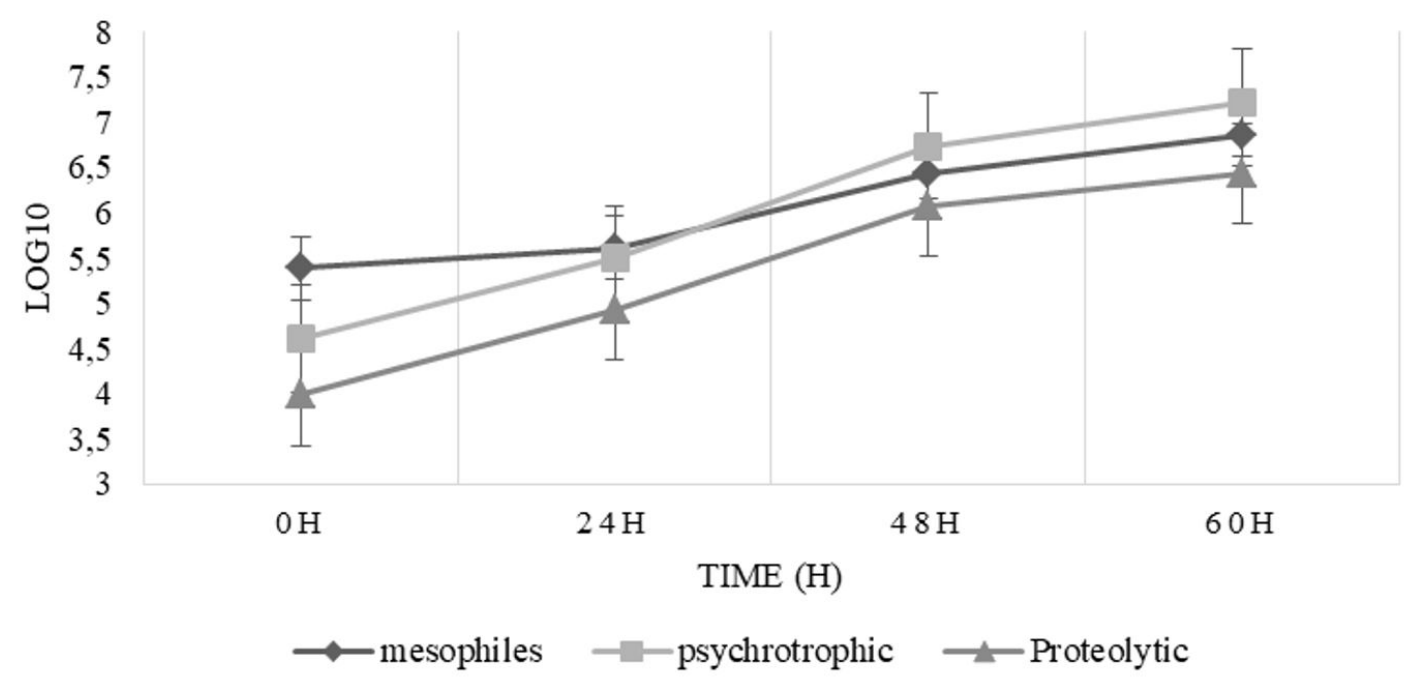

Figure 1 - Counting of mesophilic, psychrotrophic and proteolytic microorganisms at different storage times at $7^{\circ} \mathrm{C}$, in dairy farms, western Paraná, Brazil, 2016-2017.

Table 1 - Count of aerobic mesophiles, psychrotrophic and proteolytic in raw milk stored at different conditions of time and temperature in dairy farms, western Paraná, Brazil 2016-2017

\begin{tabular}{|c|c|c|c|c|c|c|}
\hline \multirow[b]{2}{*}{ Treatments } & \multicolumn{2}{|c|}{ Mesophiles ${ }^{1}$} & \multicolumn{2}{|c|}{ Psychrotrophic } & \multicolumn{2}{|c|}{ Proteolytic } \\
\hline & $\begin{array}{c}\log \\
\text { CFU/mL }\end{array}$ & SD & $\begin{array}{c}\text { Log } \\
\text { CFU/mL }\end{array}$ & SD & $\begin{array}{c}\log \\
\text { CFU/mL }\end{array}$ & SD \\
\hline Zero & $5.38^{\mathrm{a}}$ & 1.04 & $4.61^{a}$ & 0.93 & $3.99^{\mathrm{a}}$ & 0.84 \\
\hline $2 \mathrm{~h} / 25^{\circ} \mathrm{C}$ & $5.38^{\mathrm{a}}$ & 1.20 & $4.86^{b}$ & 1.03 & $4.27^{b}$ & 0.72 \\
\hline $2 \mathrm{~h} / 35^{\circ} \mathrm{C}$ & $5.48^{\mathrm{a}}$ & 1.24 & $4.75^{\mathrm{ab}}$ & 1.11 & $4.25^{\mathrm{ab}}$ & 0.79 \\
\hline $24 \mathrm{~h} / 7^{\circ} \mathrm{C}$ & $5.61^{\mathrm{a}}$ & 1.17 & $5.40^{c}$ & 1.09 & $4.93^{c}$ & 1.00 \\
\hline $48 \mathrm{~h} / 7^{\circ} \mathrm{C}$ & $6.43^{b}$ & 1.40 & $6.62^{d}$ & 1.26 & $6.07^{d}$ & 1.01 \\
\hline $60 \mathrm{~h} / 7^{\circ} \mathrm{C}$ & $6.87^{\mathrm{b}}$ & 1.34 & $7.09^{e}$ & 1.18 & $6.43^{d}$ & 0.81 \\
\hline
\end{tabular}

${ }^{1}$ Limit established by current legislation (IN31): 5.48 Log CFU. ${ }^{2}$ Average Log CFU/mL. SD: Standard Deviation. Different letters in the columns differ statistically ( $\mathrm{p}<0.05$ ). 


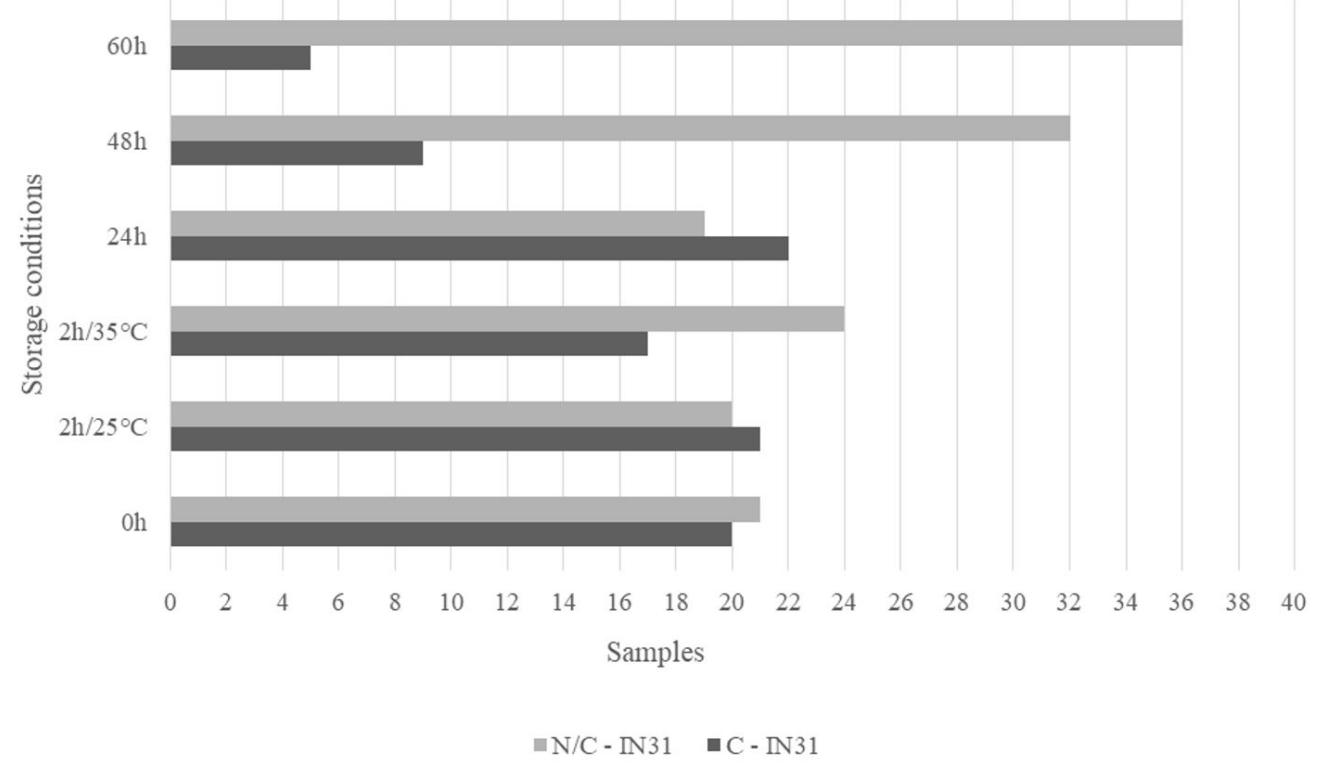

Figure 2 -Number of raw milk samples in dairy farms, western Paraná, Brazil, 2016-2017, in non-compliance and conformity at the different time and temperature conditions before the established limits of mesophilic aerobes (5.47 Log CFU/mL) of Normative Instruction 31 (IN31). N/C = Non-compliant; $\mathrm{C}=$ conformity.

considered adequate to maintain stable multiplication of mesophiles for $48 \mathrm{~h}$ when the level of initial, contamination is low (Perin et al., 2012). However, the results of the present study showed that this same condition was not sufficient to maintain milk quality, even with initial acceptable contamination, namely, in accordance with legislation.

In this context, milk with low bacterial contamination could only be stored for longer than $24 \mathrm{~h}, 96 \mathrm{~h}$ for example, provided that it is kept at a temperature below $2-4{ }^{\circ} \mathrm{C}$ without compromising its microbiological quality (Nada et al., 2012; O'Connell et al., 2016). Vithanage et al. (2017) recommend the storage of raw milk at $2{ }^{\circ} \mathrm{C}$ to control microbial multiplication and proteolytic activity in milk. Therefore, it is very important that raw milk is obtained and kept in adequate hygienic-sanitary conditions.

Milk produced in Brazil often presents quality problems, resulting in levels above the limits established by Brazilian legislation, which is also observed in Figure 2. In addition, refrigeration temperature of $7{ }^{\circ} \mathrm{C}$ determined by national legislation is above the temperature recommended in the literature (Paludetti et al., 2018; Vithanage et al., 2017).

Considering that refrigeration selects bacteria from the psychrotrophic group, it was possible to verify the significant increase in the count of these microorganisms during the storage at $7^{\circ} \mathrm{C}$ (Table 1). Although legislation does not provide specific limits for this microbial group, the counts were significantly higher in milk stored for more than $24 \mathrm{~h}$ at $7{ }^{\circ} \mathrm{C}$, indicating that these storage conditions are not adequate to maintain raw milk quality.
Most of the psychrotrophs found in milk are capable of producing proteases during their multiplication phase (Murphy et al., 2016). This ability can be verified in Table 1 and Figure 1, in which in all storage conditions, significant increases of the proteolytic were observed during milk storage.

Thus, raw milk storage time in the property must be as short as possible in order to avoid that the psychrotrophs produce lipases and thermoresistant proteases (Barbano et al., 2006). These enzymes cause reduction in industrial yield, sensorial defects in milk products and sedimentation in UHT milk, compromising the shelf-life of products (Murphy et al., 2016).

Among the group of protease-producing psychrotrophs, Pseudomonas is considered the main genus. However, Gram-positive microorganisms and some yeasts also present deteriorating potential in refrigeration temperature (Baur et al., 2015). Counts around $106 \mathrm{CFU} / \mathrm{mL}$ of psychrotrophic causes changes in dairy products (McPhee \& Griffiths, 2011). Therefore, according to the results of this study, it is possible to infer that products manufactured with milk stored at $7^{\circ} \mathrm{C}$ for $48 \mathrm{~h}$ and $60 \mathrm{~h}$ can give rise to technological defects in dairy products.

According to national legislation, the study showed that 21 samples were in disagreement with the recommended limits of mesophilic aerobes at Time Zero, with no significant difference for $24 \mathrm{~h}(\mathrm{p}>0.05)$ (Figure 2). In the condition of $7{ }^{\circ} \mathrm{C} / 48 \mathrm{~h}$, there is an increment of 11 nonconforming samples, noting the maximum storage condition proposed by IN31 does not guarantee the microbiological quality of the milk. In view of these 
results, the adaptations proposed by Normative Instruction $\mathrm{n}^{\circ} .76$ and 77 regarding the storage temperature in the rural property to $4{ }^{\circ} \mathrm{C}$ (Ministério da Agricultura, Pecuária e Abastecimento, 2018b), can help to maintain the microbiological standards over time. Further studies are needed to evaluate the effect of the storage condition at $4{ }^{\circ} \mathrm{C}$ on the mesophilic aerobic counts.

\section{Conclusion}

The storage of raw milk at $7{ }^{\circ} \mathrm{C}$ for 24 and $48 \mathrm{~h}$ is not suitable for the preservation of the product, since it allows the multiplication of mesophilic, psychrotrophic and proteolytic microorganisms, which may compromise the quality of dairy products obtained from this raw material. However, storage at $2 \mathrm{~h} / 25^{\circ} \mathrm{C}$ and $2 \mathrm{~h} / 35^{\circ} \mathrm{C}$ showed no significant changes in bacterial counts, but there was an increase in the counts of psychrotrophic and proteolytic microorganisms. Thus, the results contribute to the change in the temperature of milk storage proposed by the new Brazilian legislation.

\section{References}

Barbano DM, Ma Y, Santos MV. Influence of raw milk quality on fluid milk shelf life. J Dairy Sci. 2006;89(1, Suppl. 1):E159. http://dx.doi.org/10.3168/jds.S0022-0302(06)72360-8. PMid:16527874.

Baur C, Krewinkel M, Kranz B, von Neubeck M, Wenning M, Scherer S, Stoeckel M, Hinrichs J, Stressler T, Fischer L. Quantification of the proteolytic and lipolytic activity of microorganisms isolated from raw milk. Int Dairy J. 2015;49(1):23-9. http://dx.doi.org/10.1016/j.idairyj.2015.04.005.

Ministério da Agricultura, Pecuária e Abastecimento (Brasil). Instrução normativa n. 62, de 29 de dezembro de 2011. Regulamento Técnico de Produção, Identidade e Qualidade do Leite tipo A, o Regulamento Técnico de Identidade e Qualidade de Leite Cru Refrigerado, o Regulamento Técnico de Identidade e Qualidade de Leite Pasteurizado e o Regulamento Técnico da Coleta de Leite Cru Refrigerado e seu Transporte a Granel. Diário Oficial da União: seção 1 [Internet]. Brasília; 2011 dez 30 [cited 2019 Apr 15]. Available from: https://www.apcbrh.com. br/files/IN62.pdf

Ministério da Agricultura, Pecuária e Abastecimento (Brasil). Instrução normativa n. 31, de 29 de junho de 2018. Diário Oficial da União: seção 1 [Internet]. Brasília; 2018a jul 2 [cited 2019 Apr 15]. Available from: http://www.in.gov.

\section{Conflict of Interest}

The authors state that they have no conflicts of interest to declare.

\section{Ethics Statement}

Protocol $n^{\circ} .10 / 2019$ relating to the case report Influence of time and storage temperature on the deteriorating microbiota of raw milk, is in accordance with the Ethical Principles of Animal Experimentation, adopted by the National Council for the Control of Animal Experimentation (CONCEA) and was APPROVED by the Ethics Committee on the Use of Animals of the Palotina Sector of UFPR (CEUA/Palotina) on $04 / 02 / 2019$.

\section{Acknowledgements}

The Coordination for the Improvement of Higher Education Personnel (CAPES) for project $n^{\circ} 88881068400 / 2014-01$ and the National Council for Scientific and Technological Development (CNPq) for project nº 31052612015-9.

br/materia/-/asset_publisher/Kujrw0TZC2Mb/content/ id/28166433/do1-2018-07-02-instrucao-normativa-n-31de-29-de-junho-de-2018-28166402

Ministério da Agricultura, Pecuária e Abastecimento (Brasil). Instrução normativa $\mathrm{n} .76$, de 26 de novembro de 2018. Diário Oficial da União: seção 1 [Internet]. Brasília; 2018b nov 30 [cited 2019 Apr 15]. Available from: http:// www.in.gov.br/materia/-/asset_publisher/Kujrw0TZC2Mb/ content/id/52750137/do1-2018-11-30-instrucao-normativan-76-de-26-de-novembro-de-2018-52749894IN\%2076

Downes FP, Ito K. Compendium of methods for the microbiological examination of foods. 4th ed. Washington: American Public Health Association; 2001. http://dx.doi. org/10.2105/9780875531755.

Frank JF, Yousef AE, Frank JF. Tests for groups of microorganisms. In: Frank JF, editor. Standard methods for the examination of dairy products. Washington: American Public Health Association; 2004. Chapter 8.

Laird DT, Gambrel Lenarz SA, Scher FM, Graham E, Reddy R. Microbiological count methods. In: Maturin LJ, editor. Standard methods for the examination of dairy products. Washington: American Public Health Association; 2004. Chapter 6. 
McPhee JD, Griffiths MW. Psychrotrophic bacteria Pseudomonas spp. In: Fuquay JW, editor. Encyclopedia of dairy sciences. 2nd ed. San Diego: Academic Press; 2011. p. 379-83. http:// dx.doi.org/10.1016/B978-0-12-374407-4.00441-6.

Murphy SC, Martin NH, Barbano DM, Wiedmann M. Influence of raw milk quality on processed dairy products: how do raw milk quality test results relate to product quality and yield. J Dairy Sci. 2016;99(12):10128-49. http://dx.doi. org/10.3168/jds.2016-11172. PMid:27665134.

Nada S, Ilija D, Igor T, Jelena M, Ruzica G. Implication of food safety measures on microbiological quality of raw and pasteurized milk. Food Control. 2012;25(2):728-31. http:// dx.doi.org/10.1016/j.foodcont.2011.12.022.

O'Connell A, Ruegg PL, Jordan K, O'Brien B, Gleeson D. The effect of storage temperature and duration on the microbial quality of bulk tank milk. J Dairy Sci. 2016;99(5):3367-74. http://dx.doi.org/10.3168/jds.2015-10495. PMid:26947309.

Paludetti LF, Jordan K, Kelly AL, Gleeson D. Evaluating the effect of storage conditions on milk microbiological quality and composition. Ir J Agric Food Res. 2018;57(1):52-62. http://dx.doi.org/10.1515/ijafr-2018-0006.

Perin LM, Moraes PM, Almeida MV, Nero LA. Intereference of storage temperatures in the development of mesophilic, psychrotrophic, lipolytic and proteolytic microbiota of raw milk. Semina: Ciênc Agrár. 2012;33(1):333-42. http://dx.doi. org/10.5433/1679-0359.2012v33n1p333.

Vithanage NR, Dissanayake M, Bolge G, Palombo EA, Yeager TR, Datta N. Microbiological quality of raw milk attributable to prolonged refrigeration conditions. J Dairy Res. 2017;84(1):92-101. http://dx.doi.org/10.1017/ S0022029916000728. PMid:28252354.

Financial Support: The Coordination for the Improvement of Higher Education Personnel (CAPES) for project $n^{\circ} 88881068400 / 2014-01$ and the National Council for Scientific and Technological Development (CNPq) for project $n^{\circ} 31052612015-9$. 